\title{
Towards equitable access to medicines for the rural poor: analyses of insurance claims reveal rural pharmacy initiative triggers price competition in Kyrgyzstan
}

\author{
Brenda Waning*1, Jason Maddix ${ }^{1}$, Yorghos Tripodis ${ }^{2}$, Richard Laing ${ }^{3}$, \\ Hubert GM Leufkens ${ }^{4}$ and Manjusha Gokhale ${ }^{5}$
}

Address: ${ }^{1}$ Boston University School of Medicine, Department of Family Medicine; One Boston Medical Center Place, Dowling 5 South, Boston, MA 02118, USA, ${ }^{2}$ Boston University School of Public Health, Department of Biostatistics Crosstown, 3rd floor, 801 Massachusetts Avenue, Boston, MA 02118 USA, ${ }^{3}$ World Health Organization, Department of Policy, Standards, and Medicines CH-1211 Geneva 27, Switzerland, ${ }^{4}$ Utrecht University, Division of Pharmacoepidemiology and Pharmacotherapy PO Box 80 082, 3508 TB, Utrecht, the Netherlands and ${ }^{5}$ Boston University School of Public Health, Data Coordinating Center Crosstown, 3rd floor, 801 Massachusetts Avenue, Boston, MA 02118 USA

Email: Brenda Waning* - bwaning@bu.edu; Jason Maddix - jasonmaddix@me.com; Yorghos Tripodis - yorghos@bu.edu; Richard Laing - laingr@who.int; Hubert GM Leufkens - h.g.m.leufkens@pharm.uu.nl; Manjusha Gokhale - mgokhale@bu.edu

* Corresponding author

Published: 14 December 2009

International Journal for Equity in Health 2009, 8:43 doi:I0.1 I86/1475-9276-8-43
Received: 30 August 2009

Accepted: 14 December 2009

This article is available from: http://www.equityhealthj.com/content/8/1/43

(C) 2009 Waning et al; licensee BioMed Central Ltd.

This is an Open Access article distributed under the terms of the Creative Commons Attribution License (http://creativecommons.org/licenses/by/2.0), which permits unrestricted use, distribution, and reproduction in any medium, provided the original work is properly cited.

\begin{abstract}
Background: A rural pharmacy initiative (RPI) designed to increase access to medicines in rural Kyrgyzstan created a network of 12 pharmacies using a revolving drug fund mechanism in 12 villages where no pharmacies previously existed. The objective of this study was to determine if the establishment of the RPI resulted in the unforeseen benefit of triggering medicine price competition in pre-existing (non-RPI) private pharmacies located in the region.
\end{abstract}

Methods: We conducted descriptive and multivariate analyses on medicine insurance claims data from Kyrgyzstan's Mandatory Health Insurance Fund for the Jumgal District of Naryn Province from October 2003 to December 2007. We compared average quarterly medicine prices in competitor pharmacies before and after the introduction of the rural pharmacy initiative in October 2004 to determine the RPI impact on price competition.

Results: Descriptive analyses suggest competitors reacted to RPI prices for 21 of 30 (70\%) medicines. Competitor medicine prices from the quarter before RPI introduction to the end of the study period decreased for 17 of $30(57 \%)$ medicines, increased for 4 of 30 (13\%) medicines, and remained unchanged for 9 of $30(30 \%)$ medicines. Among the 9 competitor medicines with unchanged prices, five initially decreased in price but later reverted back to baseline prices. Multivariate analyses on 19 medicines that met sample size criteria confirm these findings. Fourteen of these $19(74 \%)$ competitor medicines changed significantly in price from the quarter before RPI introduction to the quarter after RPI introduction, with 9 of 19 (47\%) decreasing in price and 5 of $19(26 \%)$ increasing in price.

Conclusions: The RPI served as a market driver, spurring competition in medicine prices in competitor pharmacies, even when they were located in different villages. Initiatives designed to increase equitable access to medicines in rural regions of developing and transitional countries should consider the potential to leverage medicine price competition as a means of achieving their goal. Evaluations of interventions to increase rural access to medicines should include impact assessment on both formal and informal pharmaceutical markets. 


\section{Background}

Equitable access to medicines remains a challenge in developing and transitional countries, especially among the rural poor. Pharmacies in densely populated areas are always more lucrative, often leaving sparsely-populated rural regions without access to reliable sources of medicines within reasonable proximity. Even when pharmacies are physically present, medicines are often unaffordable, and their availability can be erratic because of failing public financing and supply chain management systems [1-11]. Understanding that a large number of people in developing countries seek care and medicines from the private sector, numerous private sector interventions have been mounted; however, a 2007 systematic review of private sector interventions on quality and utilization of care by the poor revealed an insufficient evidence base for those wishing to increase access to health services through private sector interventions [12].

One of the more commonly used mechanisms to address inequities in rural access to medicines has been the establishment of revolving drug funds, whereby a capital investment allows for the initial purchase of medicines and revenues from medicine sales or user fees are used to replenish stock. Sustainable and successful schemes have been described across Africa, South East Asia, and the Former Soviet Union [13-22]. More frequently, however, the literature reveals the failure of revolving drug funds to accomplish their objectives $[14,15,22-34]$.

The design and management challenges of revolving drug funds that Cross et al [22] described in 1986 remain relevant today, nearly a quarter of a century later. Most noteworthy for our study is the inability of most schemes to adopt a business approach to their operations and practices, including a failure to assess the potential market and insufficient planning and marketing [22]. The concept of revolving drug funds has evolved into more sophisticated, business-focused initiatives, such as the Tanzanian Accredited Drug Dispensing Outlets and the Ghanaian CAREshops [6,35]. However, we have found no evidence that either these more advanced initiatives or the traditional revolving drug funds have been described or evaluated with regard to their impact on the existing pharmaceutical market in a given region.

Kyrgyzstan, like many developing and transitional countries, struggles to ensure access to medicines in rural regions. Approximately 64\% of Kyrgyzstanis live in predominantly mountainous rural regions [36]. In participatory research sessions involving more than $80 \%$ of households in Naryn Province $(n=27,266)$, rural residents prioritized geographic access to pharmacies as the number one determinant of health in their communities [37]. In 2004, it was estimated that more than 300 rural villages in Kyrgyzstan had no physical access to pharmacies and medicines [38]. A number of factors underlie this absence of rural pharmacies: all pharmacies were privatized during health reforms following the dissolution of the Soviet Union, and would-be entrepreneurs believed pharmaceutical markets in rural regions were insufficient and unviable. A shortage of pharmacists in rural areas, combined with national policies that mandate pharmacies be staffed by pharmacists, created yet another deterrent to starting rural pharmacies.

When pharmacies are present in rural Kyrgyzstan, medicines are often unaffordable to the poor. The Kyrgyzstan Mandatory Health Insurance Fund covers medicines for approximately $80 \%$ of the population [39]. This insurance benefit, however, is administered through contracted private pharmacies concentrated in highly populated regions, and although rural residents are eligible for the medicines insurance benefit, they live too far away from contracted pharmacies to actually access it. Meanwhile, outpatient medicine purchases were the fastest growing component of out-of-pocket health expenditures from 2000 to 2003, increasing more than two-fold over this time period [40]. A 2005 evaluation in Jumgal District found that out-of-pocket costs for treatment of hypertension can represent up to $71 \%$ of non-food consumption per capita [38].

In 2005, the Kyrgyz Ministry of Health responded to the pharmacist human resource issue by changing the law to allow nurses to dispense medicines in pharmacies in rural regions after completing a two-week training course. A non-governmental organization (NGO), in collaboration with the Kyrgyz-Swiss Health Reform Support Project, Jumgal Village Health Committees, and the Kyrgyzstan Mandatory Health Insurance Fund, launched a rural pharmacy initiative (RPI) in Jumgal District. The RPI established pharmacies in 12 villages under a revolving drug fund mechanism. The RPI pharmacies were located in government-owned clinics and contracted with nurses already in the clinics to dispense medicines. To avoid disrupting the private market, the RPI management refrained from setting up pharmacies in Chaek, the district center, where a few pharmacies already existed. These private pharmacies also had outlets in two larger villages in Jumgal. A description of key features of the RPI is provided in Table 1.

While no distinct policy was created to establish medicine prices in the RPI, the management applied minimal markups sufficient to cover their estimated operating costs. Retail mark-ups initially averaged approximately 30-50\% for most medicines. Surprisingly, as the rural pharmacy initiative emerged, the private pharmacies in the district center appeared to be changing their prices on key medi- 
Table I: Key features of the Rural Pharmacy Initiative

\begin{tabular}{ll}
\hline Key Feature & Description \\
\hline Buy-in and Support & Popular consensus that access to medicines is the number one health determinant in communities \\
\hline Involvement of Village Health Committees in the design of the RPI and refurbishment of pharmacy outlets \\
\hline $\begin{array}{l}\text { Political will of the Kyrgyz authorities, and support from international organizations and the Mandatory } \\
\text { Health Insurance Fund }\end{array}$ \\
\hline Cost Savings and Income & $\begin{array}{l}\text { Co-location of the RPI headquarters in government offices in the capital city, resulting in free rent and } \\
\text { utilities }\end{array}$ \\
\hline Revenue stream assured by contractual arrangement between RPI pharmacies and the Mandatory Health \\
Insurance Fund for administration of state-funded medicines benefit
\end{tabular}

cines in order to compete with the new RPI pharmacies in area villages. Anecdotal reports and interviews with owners of private pharmacies in Chaek suggested that the RPI had an unplanned impact on overall medicine prices, even in the district center where the RPI was not operating.

The potential of these types of rural pharmacy initiatives to induce medicine price competition has profound implications for Kyrgyzstan and beyond. While scores of studies have been conducted to describe the unaffordability of medicines $[7,9,11]$, few publications provide evidence-based guidance on how to decrease medicine prices so they are more affordable. The purpose of this study, therefore, is to determine if the RPI actually achieved the unforeseen benefit of triggering price competition in nearby private competitor pharmacies.

\section{Methods}

We obtained six lists of medicines covered by the Kyrgyz Mandatory Health Insurance Fund from 2002-2007 along with pharmaceutical claims data $(\mathrm{n}=162,999$ claims) for the period October 2003-December 2007 for the districts Ak Taala, Alai, At Bashi, Jumgal, Kochkor, Naryn, Toktogul, and Ton. We cleaned insurance claims data in several steps, excluding the following: reimbursement equaled zero; those where patient co-pay plus reimbursement did not equal total reimbursement; those with invalid package sizes; and those where the difference in published and actual reimbursement rates exceeded $20 \%$.
Differences in published and actual reimbursement prices result from a delay in actually distributing the revised published lists to the more than 300 contracted pharmacies throughout the region. We then excluded all nonJumgal claims and all claims for medicines not on the list of top 30 selling medicines by volume, resulting in a final analytic data set of 18,012 Jumgal claims, which included 6,795 and 11,217 claims from RPI and competitor pharmacies, respectively (Figure 1).

We examined RPI and competitor prices using both simple descriptive and multivariate analyses. Since the RPI was first introduced in October 2004, this study period allows for a one-year observation period of competitor medicines prices before the introduction of the RPI and more than three years of observation for both RPI and competitor pharmacies afterwards. All prices are provided as price per unit (price per tablet or price per injection) in Kyrgyz Som.

For descriptive purposes, we calculated competitor price changes by comparing their average price for the last quarter observed in the study to their average price in the quarter preceding the first RPI price observed. Competitor final price changes are presented as percent price changes (Figure 2, Table 2) and calculated as follows: ((average price last quarter - average price quarter before RPI introduction $)$ /average pricequarter before RPI introduction) $\times 100$. We plotted examples of competitor price changes for medicines that exhibited price decreases, price increases, and no price changes (Fig- 


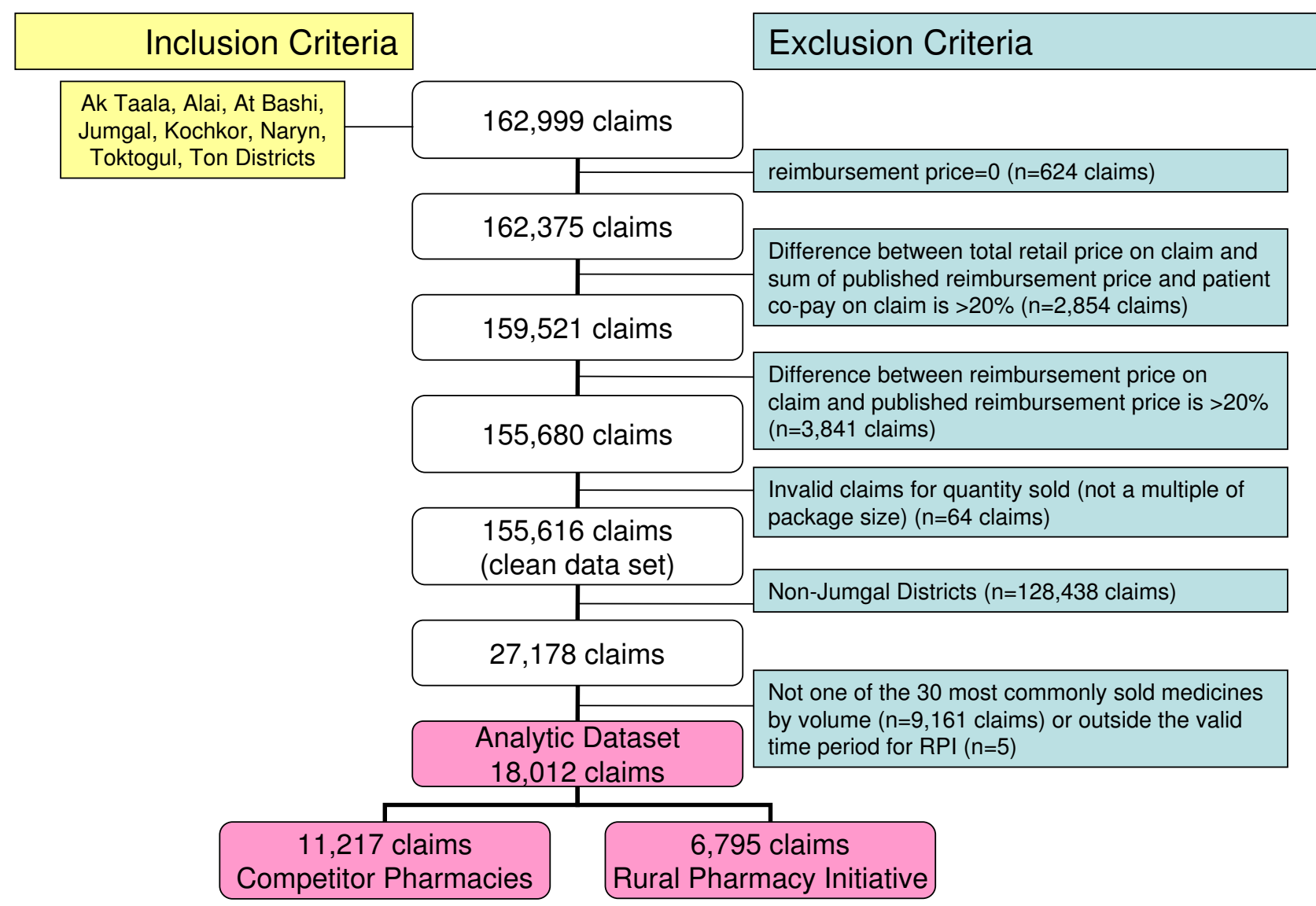

Figure I

Creation of Analytic Data Set from Medicines Insurance Claims.

ures $3,4,5$, and 6 ). The Health Insurance Fund reimbursement prices are provided as a reference but are not meant to be an indicator of retail prices. The reimbursement price is the amount reimbursed to pharmacies by the Health Insurance Fund, whereby the patient pays the difference between the retail and reimbursement prices. Each medicine has a unique reimbursement price, ranging from $30-100 \%$ of the retail price. These reimbursement prices are changed regularly but these changes are typically not related to changes in retail prices.

We conducted multiple regression analysis on 19 of the top 30 selling medicines which met our sample size inclusion criteria that required at least seventeen quarters of competitor price data, including three quarters of data before RPI introduction and at least nine quarters of RPI price data. In quarters with missing data due to sparse pur- chases, we imputed the price and number of transactions using the adjacent quarters.

We estimated competitor prices for 3 time periods: the immediate price change from the quarter before the RPI was introduced to the quarter after the RPI was introduced (Table 3, Column B), quarterly trends prior to the RPI introduction (Table 3, Column $\mathrm{C}$ ), and the long term quarterly price trends after the RPI introduction (Table 3, Column D). When quarterly price trends before RPI introduction are equal to quarterly price trends after RPI introduction, we present the overall quarterly rate of change (Table 3, Column E). Statistical significance is defined as $\mathrm{p} \leq 0.05$.

We conducted model checking diagnostics, including a test for residual autocorrelation, to ensure our model was 


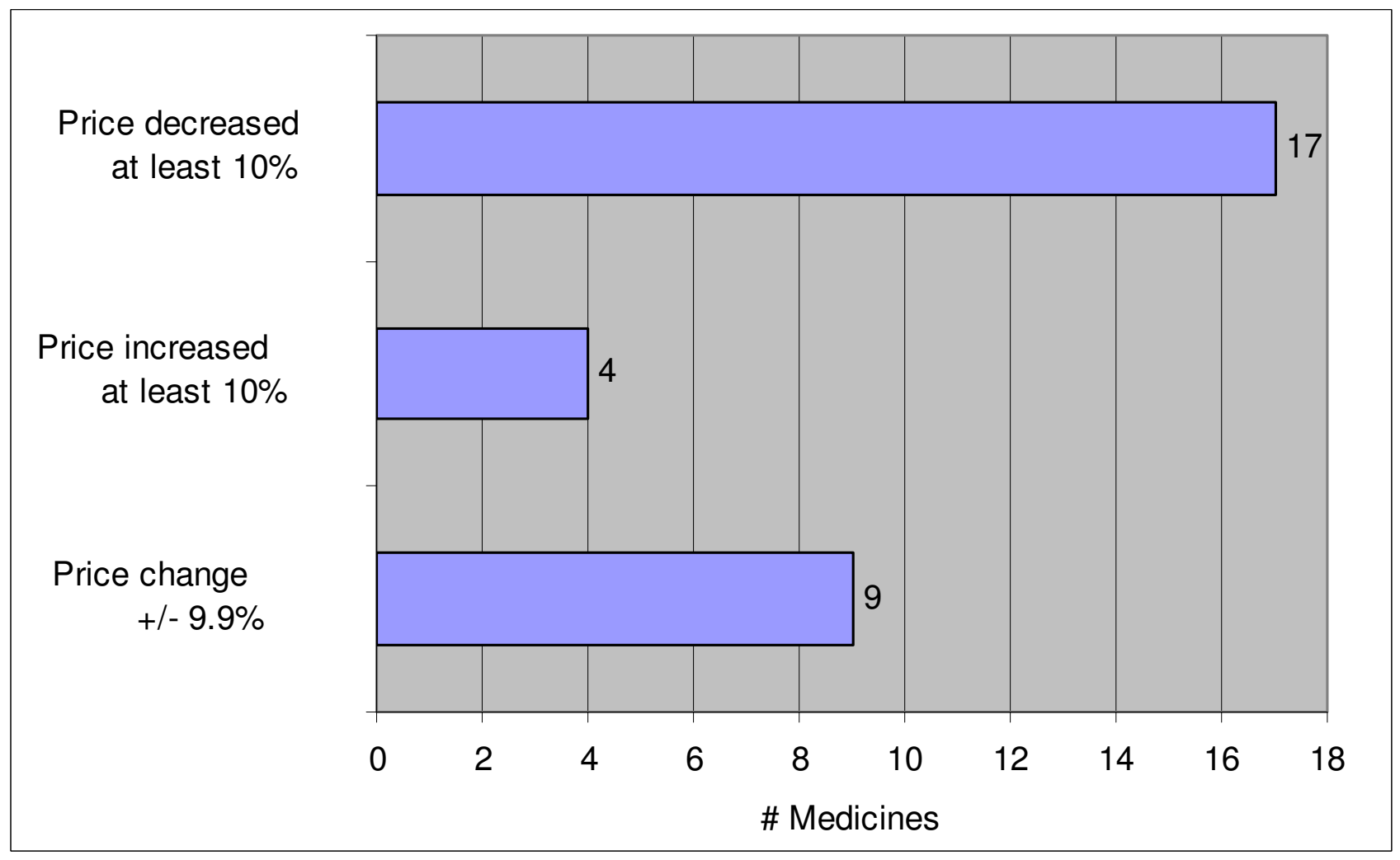

Figure 2

Competitor medicine price changes after the RPI introduction. Price change from quarter before observation of first RPI price to last study observation price.

appropriate for our distribution. Our model takes into account price dispersion because it utilizes all price values, not just average price. But we present the average price to facilitate interpretation of the results. We conducted all descriptive and multivariate analyses using SAS 9.1 (SAS Institute, Carey, NC).

\section{Results}

Descriptive analyses reveal that prices for 21 of $30(70 \%)$ competitor medicines changed by at least $10 \%$ to mimic RPI prices after the introduction of the RPI. Prices for 17 of $30(57 \%)$ competitor medicines decreased at least $10 \%$, with price decreases ranging 10-64.3\% (Figure 2). Prices for 4 of $30(13 \%)$ competitor medicines increased more than $10 \%$, with price increases ranging 12.1-222.2\%, apparently in response to RPI prices introduced at higher rates than those charged by competitors. Nine of 30 (30\%) competitor medicines revealed price changes +/$9.9 \%$ after the RPI introduction.

Detailed information on specific medicine price changes is provided in Table 2. Among the seventeen competitor medicine prices that decreased at least $10 \%$ after RPI introduction, six, seven, and four medicines showed price reductions of $41-64 \%, 20-40 \%$, and $10-19 \%$, respectively. Among the four competitor medicines that increased more than $10 \%$ after RPI introduction, three were ironcontaining medicines.

Two examples where competitor medicine prices decreased after RPI introduction are provided in Figures 3 and 4 . Figure 3 reveals dramatic competitor price reductions for metronidazole $500 \mathrm{mg}$ vaginal suppositories where the competitor price decreases immediately from 11.9 Kyrgyz Som/suppository prior to RPI introduction to 7.9 in the following quarter. The quarterly trends continue downward to a final price of $6.5 \mathrm{Kyrgyz}$ Som/suppository at the end of the study period.

In Figure 4, the competitor price for enalapril 20mg tablets $\left(\right.$ Ednyt $\left.^{\circledR}\right)$ was $10.5 \mathrm{Kyrgyz}$ Som/tablet in the quarter prior to the introduction of RPI pharmacies. The RPI entry price was 5.4 Kyrgyz Som but they soon increased their price to $8.1 \mathrm{Kyrgyz}$ Som. A few quarters later, the competitors priced their product to mimic the RPI prices, also ending at 8.1 Kyrgyz Som at the end of the study. 


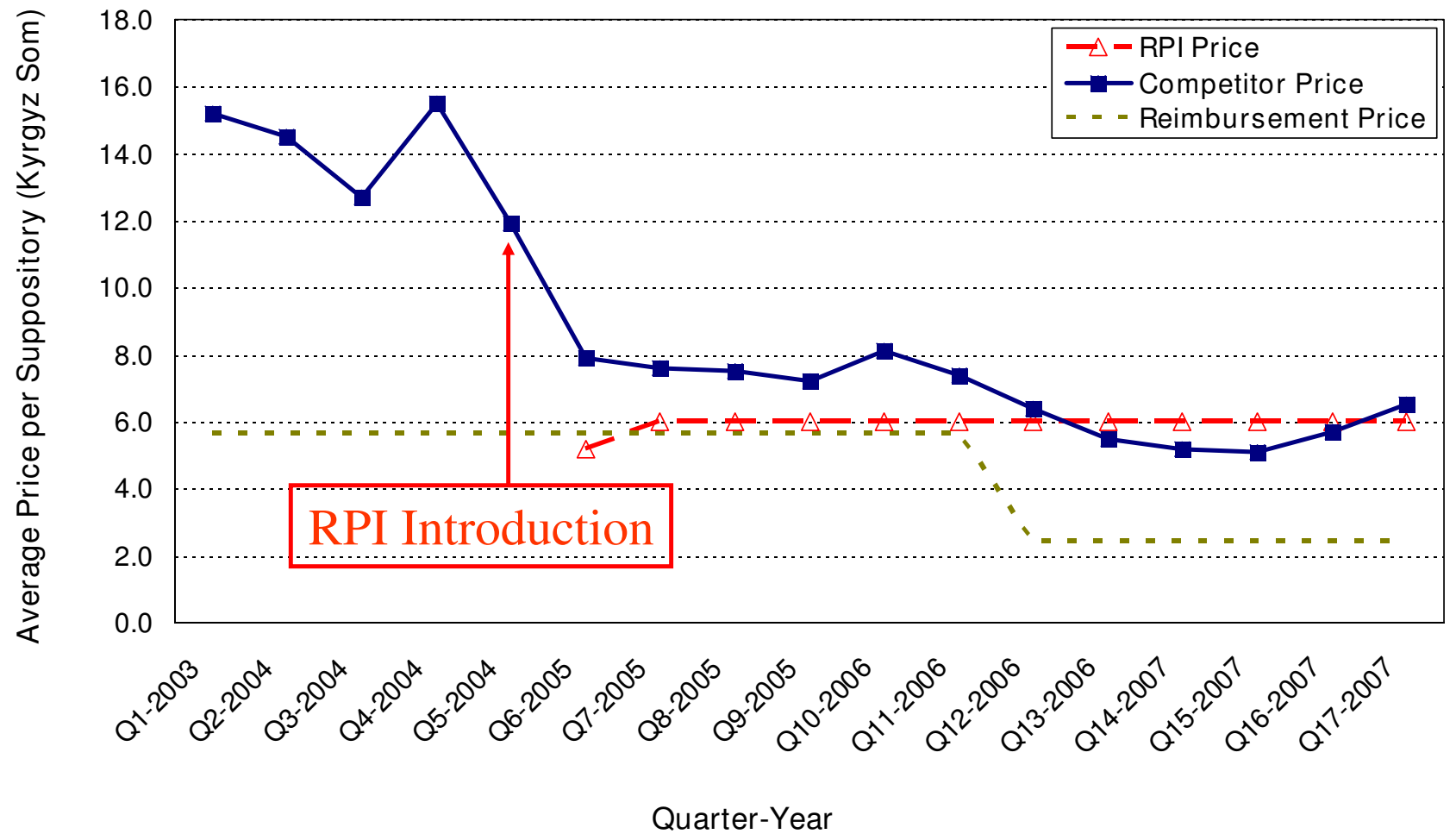

Figure 3

Price changes for metronidazole $500 \mathrm{mg}$ vaginal suppositories.

Figure 5 illustrates dramatic price increases observed for tablets containing iron and ascorbic acid (Gyno-Tardyferon $^{\circledR}$ ) in response to these products being sold at higher prices in RPI pharmacies. Competitor prices increased from 3.8 Kyrgyz Som/tablet to 8.2 Kyrgyz Som/tablet after the RPI pharmacies introduced the product at the price of 8.2 Kyrgyz Som/tablet.

Lastly, figure 6 provides an example of a medicine that exhibits no overall price change from the quarter before the RPI is introduced and the end of the study period. While competitor prices fall for a brief period of time, the pharmacies eventually revert to prices charged prior to the introduction of the RPI.

Multivariate analysis revealed fourteen of nineteen (74\%) competitor medicines with significant price changes from the quarter before RPI introduction to the quarter after RPI introduction (Table 3, Column B). Nine of the nineteen $(47 \%)$ medicines revealed price decreases, which ranged from ranged from 0.35-4.85 Kyrgyz Som per unit, while five of the nineteen (26\%) revealed price increases, ranging from 0.06-1.96 Kyrgyz Som per unit.
Interestingly, among medicines with differences in price trends before and after the RPI introduction, 6 of 6 $(100 \%)$ revealed downward price trends before the RPI (Table 3, Column C). All six of these medicines revealed significant price decreases immediately after RPI introduction (Table 3, Column B) with long term prices remaining relatively unchanged (Table 3 , Column D).

Mixed results are noted among thirteen medicines with no differences in price trends before and after RPI introduction. Seven of these 13 (54\%) medicines showed downward price trends, while prices for 3 of the $13(23 \%)$ trended upward (Table 3, Column E). For most of these medicines, the changes in price trends over time (Table 3, Column E) are far less than those observed immediately after the introduction of the RPI (Table 3, Column B).

\section{Discussion}

This study confirms the success of the RPI as an innovative, not-for-profit option for promoting medicine price competition in Kyrgyzstan, and ultimately increasing access to medicines. The RPI not only addressed geographic access by enabling rural residents to buy medi- 


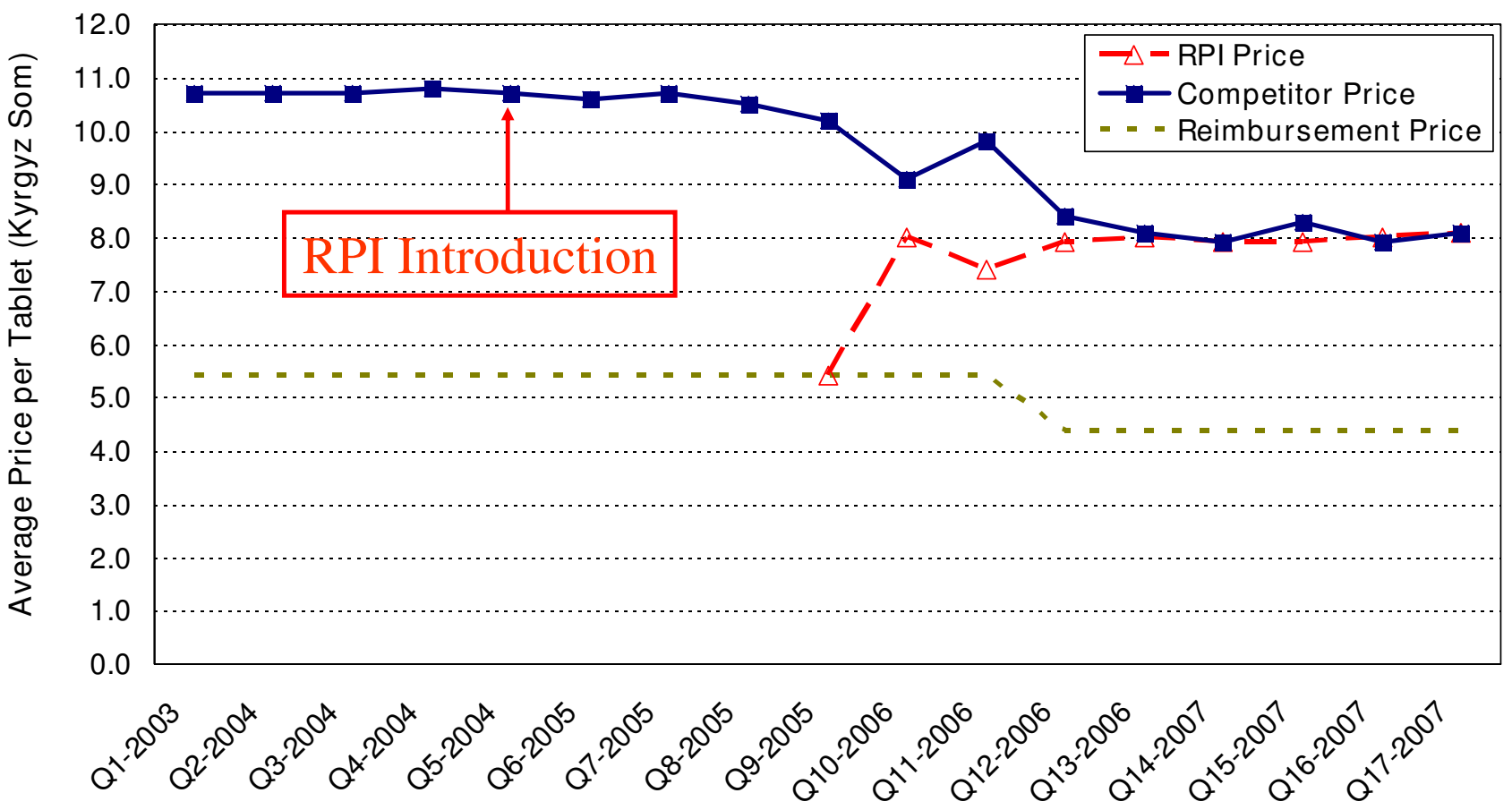

Quarter-Year

\section{Figure 4}

Price changes for enalapril 20 mg tablets (Ednyt ${ }^{\circledR}$ ).

cines in their own villages, it also spurred dramatic price competition in private pharmacies located in the district center. Thus, the RPI's impact was far greater than anticipated as the new pharmacies managed also to increase access to medicines in other villages through the competitive price reductions they engendered. The ultimate result was more affordable medicine for both villagers and residents of the district center. It is worth noting, however, that for some medicines, when the RPI introduced prices higher than competitor prices, the competitor increased their prices to match those of the RPI. In this regard, the RPI demonstrates power to drive markets both downward and upward in price.

We do not believe the RPI resulted in the institution of a rural market. Instead, we believe the market already existed in Jumgal prior to the RPI and that the entry of the not-for-profit RPI spurred a more competitive market. Indeed, demand for medicines was already documented before the RPI when villagers identified access to medicines as their number one health concern. On the supply side, medicines were available in the rayon center, but not in the villages themselves. Prior to the establishment of the RPI, villagers either hired a taxi to deliver medicines from existing pharmacies to their homes or they secured some means of transport to travel outside the village to the nearest pharmacy. The establishment of the RPI, therefore, took business away from the existing pharmacies despite being located far away. The emergence of the RPI pharmacies also seems to have stimulated expansion of the private sector into new villages. Owners of pharmacies in the rayon center opened two branch pharmacies in two of the larger villages, perhaps in an attempt to minimize loss of business in the rayon center.

While we have no means to assess price collusion, we suspect that some degree of collusion existed among the private pharmacies that were established prior to the RPI. We therefore suspect the introduction of the RPI disrupted any existing price collusion in the region. Given that our study tracks prices for three years after the establishment of the RPI, we suspect the competitors' price reactions are sustained and not a one-off reaction to the RPI.

When the competitors change prices to mimic RPI medicine prices, their prices are often near identical to the RPI prices. We were unable to fully ascertain how the competitors gained market intelligence on RPI medicine prices. 


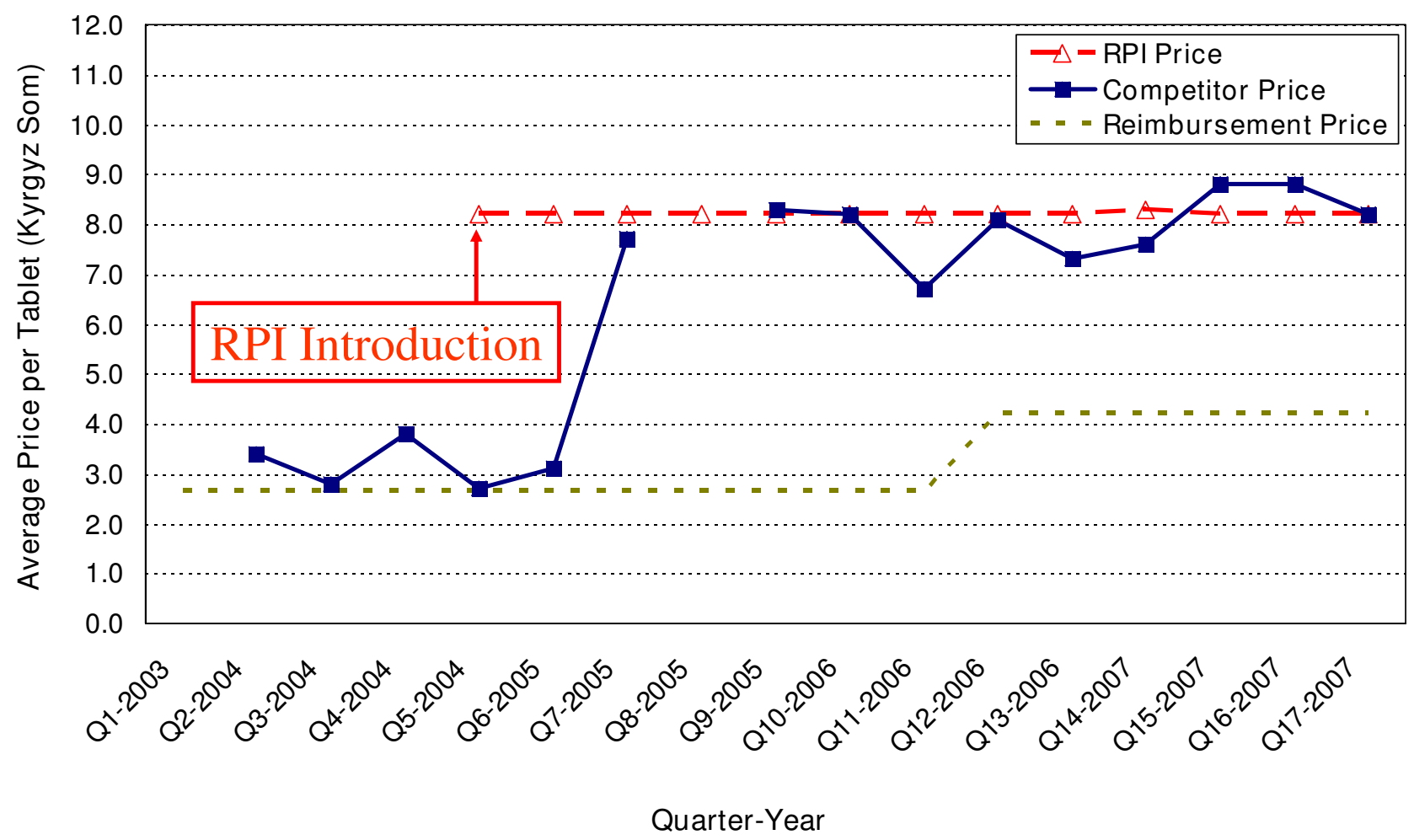

Figure 5

Price changes for ferrous sulfate+ascorbic acid (Gyno-Tardyferon ${ }^{\circledR}$ ) tablets.

Upon establishment of the RPIs, the RPI nurses were instructed to display all medicines with price tags affixed to their packages. When interviewed a few months later, the nurses told investigators that they no longer displayed medicine prices because employees from competitor pharmacies would visit RPI pharmacies and record medicine prices. The RPI nurses, management, and others were greatly concerned about predatory pricing by competitor pharmacies. The RPI was quite fragile when first established and many feared the existing private sector pharmacies would intentionally undercut RPI prices in order to drive them out of business. Our results suggest that competitors are still obtaining price information from RPI pharmacies even though price tags are no longer affixed.

While our study provides compelling results, it has limitations. First, we were only able to access prices for those medicines covered by the Health Insurance Fund. The sale of all medicines covered by the Health Insurance Fund, however, accounted for $51 \%$ of total RPI revenue in the fourth quarter of 2007 [41]. Because these pharmacies serve sparsely-populated rural regions, small sample sizes limited us to analyzing only 19 of the 30 top-selling med- icines with multivariate methods. Some medicines that passed our sample size criteria for multivariate analysis had limited insurance claims prior to or after RPI introduction. We utilized a linear model that assumes a relatively constant quarter-on-quarter price change. Given that we only observed seventeen quarters of data, we believe the linear assumption is reasonable. Model checking diagnostics, such as test for residual autocorrelation, showed that our model is adequate for our purposes.

Furthermore, we note that to make optimum use of space, we provided price trends in graphic form for only four of the thirty medicines studied, however a full set of figures is provided in Additional File 1. Figures provided in this paper depict the three types of competitor price changes observed after the introduction of the RPI-price decreases, price increases, and no price changes-and are representative of the medicines in each price change category. We had no means to determine why some medicines exhibited dramatic price changes and others remained unchanged. While we had no data on the quality of medicines, we do not believe that quality confounded our price findings. For branded generic medicines, we assume 


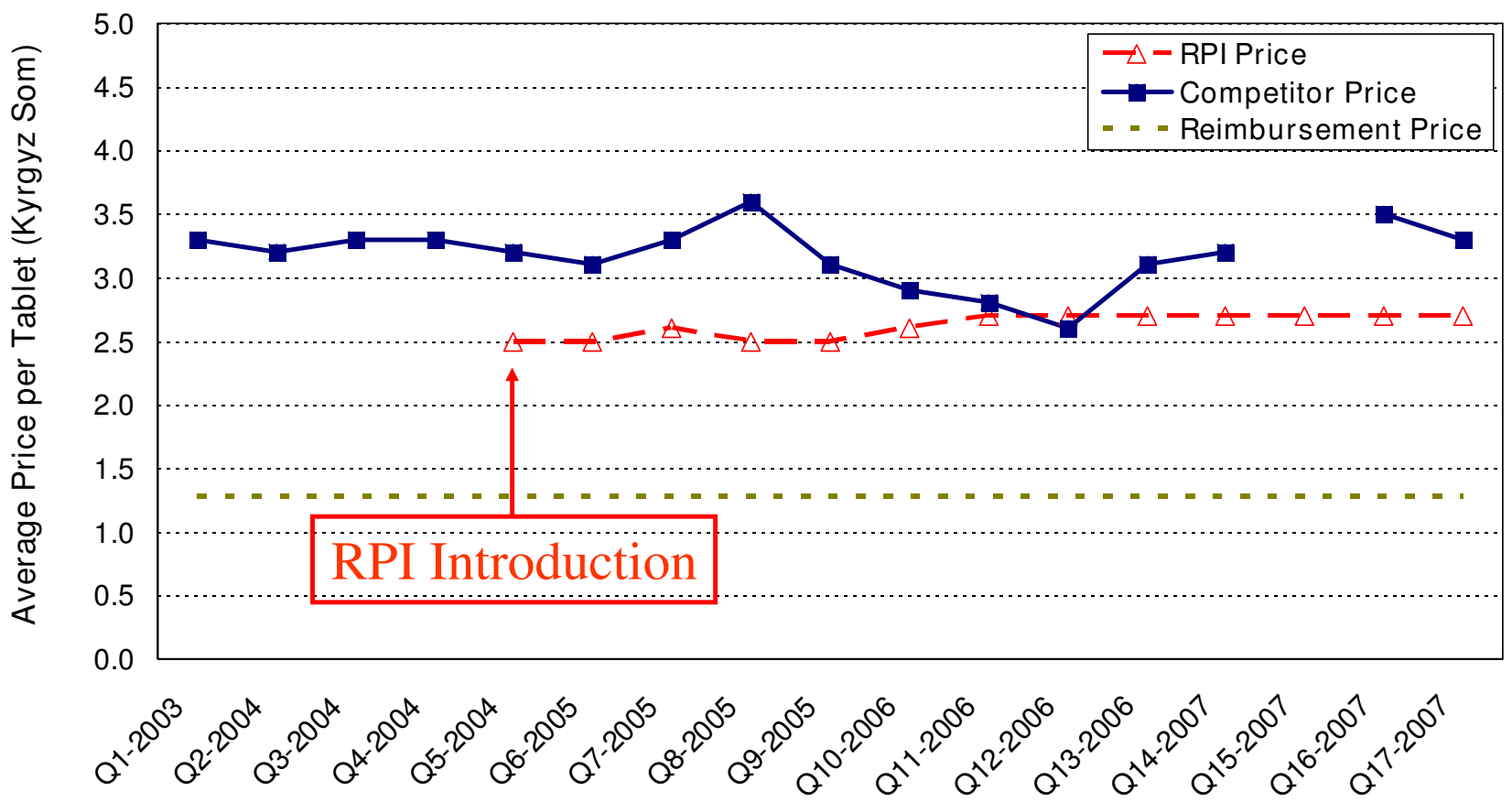

Quarter-Year

\section{Figure 6}

Price changes for erythromycin $250 \mathrm{mg}$ tablets.

the quality of medicines to be identical in RPI and nonRPI pharmacies. Because the RPI and non-RPI pharmacies purchase medicines from the same wholesalers in Bishkek, we assume quality of non-branded generic medicines is comparable. We have no evidence of pharmacies over-charging insurers, however we expect it happens to some degree. Over-charging is less likely to happen within the RPI because it is supervised by staff from the Mandatory Health Insurance Fund.

While research on market impact is typically complicated due to many concurrent interventions and changing market conditions, we are confident that the market in Jumgal is truly local and has no other large-scale interventions that might be responsible for our findings. Indeed, even an annual inflation of $10 \%$ [42] did not seem to affect medicine prices in this region over the study period. We decided to use current medicine prices in lieu of adjusting prices for inflation after noting that most medicine prices trended downward or remained unchanged over the 4 years and did not seem to follow the national inflation rate. We are not sure why medicine price trends are inconsistent with national inflation trends. We suspect that medicine prices were already priced at the highest prices the market could bear or that national inflation rates simply do not represent the price trends in rural medicine markets. Lastly, we have no means of determining if the market existing prior to the RPI was competitive or collusive with regards to price setting.

Our study was designed only to assess whether the RPI induced regional price competition and not to evaluate rational use of medicines in RPI pharmacies. Others have shown that perverse incentives to misuse medicines may result when prescribers benefit from medicine sales [43]. In this study, we note that ampicillin injection has the highest sales volume and the largest number of insurance claims (Table 2), suggesting overuse of both antibiotics and injections. Additional research is needed to assess the impact of the RPI on rational use of medicines.

Similarly, our study does not aim to explain why the RPI has been successful or how the RPI has been sustainable amidst other documented failures to increase access to medicines in rural regions. The RPI may offer a model that can be scaled up across many more regions and in other parts of Central Asia, but it is important to first determine the most critical elements that led to its success. While we 
Table 2: Descriptive results of RPI and competitor prices for the $\mathbf{3 0}$ highest volume insurance medicines before and after RPI introduction

\begin{tabular}{|c|c|c|c|c|c|c|c|c|}
\hline \multirow[t]{2}{*}{ Volume Rank* } & \multicolumn{2}{|c|}{$\begin{array}{c}\text { Total \# Claims } \\
\text { (RPI and Competitor) }\end{array}$} & \multirow{2}{*}{$\begin{array}{l}\text { Generic } \\
\text { Medicine Name } \\
\text { (Brand Name) }\end{array}$} & \multicolumn{2}{|c|}{$\begin{array}{l}\text { Average Initial Price per Unit (SD) } \\
\text { in Kyrgyz Som }\end{array}$} & \multicolumn{2}{|c|}{$\begin{array}{c}\text { Average Final Price per Unit (SD) } \\
\text { in Kyrgyz Som }\end{array}$} & \multirow{2}{*}{$\begin{array}{l}\text { Competitor } \\
\text { Price Change } \\
\text { after RPI } \\
\text { Introduction** }\end{array}$} \\
\hline & $\begin{array}{l}\text { Before RPI } \\
\text { Introduction }\end{array}$ & $\begin{array}{c}\text { After RPI } \\
\text { Introduction }\end{array}$ & & Competitor & RPI & Competitor & $\mathbf{R P I}$ & \\
\hline$I^{*}$ & 630 & 1,923 & $\begin{array}{l}\text { ampicillin } 500 \mathrm{mg} \\
\text { injection }\end{array}$ & $\begin{array}{l}7.6 \\
(0.6)\end{array}$ & $\begin{array}{l}6.0 \\
(0.0)\end{array}$ & $\begin{array}{l}7.7 \\
(0.5)\end{array}$ & $\begin{array}{l}6.0 \\
(0.1)\end{array}$ & $+1.3 \%$ \\
\hline 2 & 0 & 494 & $\begin{array}{l}\text { amoxicillin } 250 \mathrm{mg} \\
\text { capsules }\end{array}$ & $\begin{array}{l}3.0 * * * \\
(0.0)\end{array}$ & $\begin{array}{c}2.5 \\
(0.0)\end{array}$ & $\begin{array}{l}3.0 \\
(0.0)\end{array}$ & $\begin{array}{c}2.5 \\
(0.0)\end{array}$ & $0 \%$ \\
\hline $3^{*}$ & 467 & 1,138 & $\begin{array}{l}\text { benzylpenicillin I } \mathrm{g} \\
\text { injection }\end{array}$ & $\begin{array}{l}5.0 \\
(0.0)\end{array}$ & $\begin{array}{c}4.8 \\
(0.2)\end{array}$ & $\begin{array}{l}5.0 \\
(0.0)\end{array}$ & $\begin{array}{l}5.0 \\
(0.2)\end{array}$ & $0 \%$ \\
\hline $4 *$ & 67 & 680 & $\begin{array}{l}\text { erythromycin } 250 \\
\text { mg tablets }\end{array}$ & $\begin{array}{l}3.3 \\
(0.2)\end{array}$ & $\begin{array}{c}2.5 \\
(0.0)\end{array}$ & $\begin{array}{l}3.3 \\
(0.4)\end{array}$ & $\begin{array}{l}2.7 \\
(0.0)\end{array}$ & $0 \%$ \\
\hline $5 *$ & 130 & 870 & $\begin{array}{l}\text { amoxicillin } 250 \mathrm{mg} \\
\text { tablets }\end{array}$ & $\begin{array}{l}3.0 \\
(0.7)\end{array}$ & $\begin{array}{l}2.6 \\
(0.2)\end{array}$ & $\begin{array}{c}2.8 \\
(0.8)\end{array}$ & $\begin{array}{c}2.5 \\
(0.0)\end{array}$ & $-6.7 \%$ \\
\hline $6^{*}$ & 342 & 779 & $\begin{array}{l}\text { atenolol } 50 \mathrm{mg} \\
\text { tablets }\end{array}$ & $\begin{array}{l}1.6 \\
(0.1)\end{array}$ & $\begin{array}{l}1.1 \\
(0.0)\end{array}$ & $\begin{array}{l}0.9 \\
(0.1)\end{array}$ & $\begin{array}{l}0.9 \\
(0.0)\end{array}$ & $-43.8 \%$ \\
\hline $7^{*}$ & 3 & 544 & $\begin{array}{l}\text { ciprofloxacin } 250 \\
\text { mg tablets }\end{array}$ & $\begin{array}{c}4.3 \\
(0.5)\end{array}$ & $\begin{array}{c}2.4 \\
(0.5)\end{array}$ & $\begin{array}{c}3.5 \\
(0.8)\end{array}$ & $\begin{array}{l}2.8 \\
(0.2)\end{array}$ & $-18.6 \%$ \\
\hline $8^{*}$ & 130 & 1,036 & $\begin{array}{l}\text { enalapril } 20 \mathrm{mg} \\
\text { tablets } \\
\left(\text { Ednyt }^{\circledR}\right)\end{array}$ & $\begin{array}{l}10.5 \\
(1.0)\end{array}$ & $\begin{array}{c}5.4 \\
(0.0)\end{array}$ & $\begin{array}{l}8.1 \\
(0.5)\end{array}$ & $\begin{array}{l}8.1 \\
(1.0)\end{array}$ & $-22.9 \%$ \\
\hline $9 *$ & 515 & 760 & $\begin{array}{l}\text { metronidazole } 250 \\
\mathrm{~m} \text { tablets }\end{array}$ & $\begin{array}{l}1.0 \\
(0.2)\end{array}$ & $\begin{array}{l}0.8 \\
(0.0)\end{array}$ & $\begin{array}{l}0.9 \\
(0.0)\end{array}$ & $\begin{array}{l}0.6 \\
(0.1)\end{array}$ & $-10 \%$ \\
\hline $10^{*}$ & 5 & 226 & $\begin{array}{l}\text { ferrous } \\
\text { sulfate+folic } \\
\text { acid+ascorbic acid } \\
\text { tablets } \\
(\text { Gyno- } \\
\left.\text { Tardyferon }{ }^{\circledR}\right)\end{array}$ & $\begin{array}{c}3.8 \\
(1.6)\end{array}$ & $\begin{array}{l}8.2 \\
(0.0)\end{array}$ & $\begin{array}{l}8.2 \\
(0.8)\end{array}$ & $\begin{array}{l}8.2 \\
(0.0)\end{array}$ & $+115.8 \%$ \\
\hline
\end{tabular}




\begin{tabular}{|c|c|c|c|c|c|c|c|c|}
\hline $11^{*}$ & 12 & 214 & $\begin{array}{l}\text { carbamazepine } 200 \\
\text { mg tablets }\end{array}$ & $\begin{array}{l}1.9 \\
(0.6)\end{array}$ & $\begin{array}{c}2.0 \\
(0.0)\end{array}$ & $\begin{array}{l}1.5 \\
(0.1)\end{array}$ & $\begin{array}{c}1.4 \\
(0.0)\end{array}$ & $-21.1 \%$ \\
\hline $12 *$ & 3 & 268 & $\begin{array}{l}\text { ferrous } \\
\text { sulfate+ascorbic } \\
\text { acid tablets } \\
\left(\text { Taryferon }^{\circledR}\right)\end{array}$ & $\begin{array}{c}2.7 \\
(0.0)\end{array}$ & $\begin{array}{l}7.3 \\
(0.0)\end{array}$ & $\begin{array}{c}8.7 \\
(1.2)\end{array}$ & $\begin{array}{c}7.3 \\
(0.0)\end{array}$ & $+222.2 \%$ \\
\hline 13 & 43 & 314 & $\begin{array}{l}\text { enalapril } 10 \mathrm{mg} \\
\text { tablets } \\
\left.\text { (Ednyt }^{\circledR}\right)\end{array}$ & $\begin{array}{l}6.9 \\
(1.2)\end{array}$ & $\begin{array}{l}5.1 \\
(0.2)\end{array}$ & $\begin{array}{l}5.0 \\
(0.6)\end{array}$ & $\begin{array}{c}5.2 \\
(0.0)\end{array}$ & $-27.5 \%$ \\
\hline 14 & 150 & 429 & $\begin{array}{l}\text { co-trimoxazole } \\
480 \mathrm{mg} \text { tablets }\end{array}$ & $\begin{array}{l}2.6 \\
(0.3)\end{array}$ & $\begin{array}{l}1.8 \\
(0.0)\end{array}$ & $\begin{array}{c}2.7 \\
(0.3)\end{array}$ & $\begin{array}{l}1.9 \\
(0.0)\end{array}$ & $+3.8 \%$ \\
\hline 15 & 0 & 187 & $\begin{array}{l}\text { iron combination } \\
\text { tablets } \\
\text { (Ferum Lek }^{\circledR} \text { ) }\end{array}$ & $\begin{array}{l}6.4^{* *} \\
(1.0)\end{array}$ & $\begin{array}{l}10.0 \\
(0.0)\end{array}$ & $\begin{array}{c}7.5 \\
(1.9)\end{array}$ & $\begin{array}{l}10.3 \\
(1.3)\end{array}$ & $+17.2 \%$ \\
\hline $16^{*}$ & 53 & 209 & $\begin{array}{l}\text { nifedipine } 20 \mathrm{mg} \\
\text { retard tablets } \\
\text { (Corinafar } \\
\text { Retard }^{\circledR} \text { ) }\end{array}$ & $\begin{array}{l}3.3 \\
(0.9)\end{array}$ & $\begin{array}{l}3.6 \\
(0.3)\end{array}$ & $\begin{array}{l}3.7 \\
(0.7)\end{array}$ & $\begin{array}{l}5.0 \\
(0.0)\end{array}$ & $+12.1 \%$ \\
\hline $17 *$ & 7 & 49 & $\begin{array}{l}\text { Prednisolone } 5 \mathrm{mg} \\
\text { tablets }\end{array}$ & $\begin{array}{l}1.1 \\
(0.1)\end{array}$ & $\begin{array}{l}1.3 \\
(0.4)\end{array}$ & $\begin{array}{c}0.5 \\
(0.0)\end{array}$ & $\begin{array}{c}0.9 \\
(0.5)\end{array}$ & $-54.5 \%$ \\
\hline $18^{*}$ & 138 & 193 & $\begin{array}{l}\text { diclofenac } 25 \mathrm{mg} \\
\text { tablets } \\
\text { (Ortophen }^{\circledR} \text { ) }\end{array}$ & $\begin{array}{c}0.7 \\
(0.2)\end{array}$ & $\begin{array}{c}0.4 \\
(0.0)\end{array}$ & $\begin{array}{c}0.6 \\
(0.1)\end{array}$ & $\begin{array}{l}0.6 \\
(0.1)\end{array}$ & $-14.3 \%$ \\
\hline 19 & 114 & 197 & $\begin{array}{l}\text { ampicillin } 250 \mathrm{mg} \\
\text { tablets }\end{array}$ & $\begin{array}{l}1.9 \\
(0.1)\end{array}$ & $\begin{array}{c}1.4 \\
(0.0)\end{array}$ & $\begin{array}{c}1.5 \\
(0.0)\end{array}$ & $\begin{array}{l}1.6 \\
(0.0)\end{array}$ & $-21.1 \%$ \\
\hline 20 & 484 & 395 & $\begin{array}{l}\text { co-trimoxazole } \\
480 \mathrm{mg} \text { Tablets } \\
\left.\text { (Biseptol }{ }^{\circledR}\right)\end{array}$ & $\begin{array}{c}4.0 \\
(0.0)\end{array}$ & $\begin{array}{c}2.2 \\
(0.0)\end{array}$ & $\begin{array}{c}3.5 \\
(0.0)\end{array}$ & $\begin{array}{c}3.8 \\
(0.0)\end{array}$ & $-12.50 \%$ \\
\hline 21 & 43 & 74 & $\begin{array}{l}\text { drotaverine } 40 \mathrm{mg} \\
\text { tablets } \\
\left(\mathrm{No}-\mathrm{Spa}^{\circledR}\right)\end{array}$ & $\begin{array}{c}2.4 \\
(0.2)\end{array}$ & $\begin{array}{c}2.3 \\
(0.0)\end{array}$ & $\begin{array}{c}2.5 \\
(0.0)\end{array}$ & $\begin{array}{c}2.6 \\
(0.0)\end{array}$ & $+4.2 \%$ \\
\hline 22 & 28 & 110 & $\begin{array}{l}\text { metronidazole } 250 \\
\mathrm{mg} \text { tablets } \\
\text { (Trichopol }^{\circledR} \text { ) }\end{array}$ & $\begin{array}{c}3.5 \\
(0.4)\end{array}$ & $\begin{array}{l}2.1 \\
(0.0)\end{array}$ & $\begin{array}{c}3.5 \\
(0.0)\end{array}$ & $\begin{array}{c}3.5 \\
(0.0)\end{array}$ & $0 \%$ \\
\hline
\end{tabular}




\begin{tabular}{|c|c|c|c|c|c|c|c|c|}
\hline $23^{*}$ & 73 & 548 & $\begin{array}{l}\text { metronidazole } 500 \\
\text { mg vaginal } \\
\text { suppositories }\end{array}$ & $\begin{array}{l}11.9 \\
(5.3)\end{array}$ & $\begin{array}{c}5.2 \\
(0.0)\end{array}$ & $\begin{array}{c}6.5 \\
(0.8)\end{array}$ & $\begin{array}{c}6.0 \\
(0.0)\end{array}$ & $-45.4 \%$ \\
\hline 24 & 13 & 60 & $\begin{array}{l}\text { ferrous } \\
\text { sulfate+ascorbic } \\
\text { acid drag } \\
\left(\text { Ferroplek }^{\circledR}\right)\end{array}$ & $\begin{array}{c}1.5 \\
(0.5)\end{array}$ & $\begin{array}{c}0.8 \\
(0.0)\end{array}$ & $\begin{array}{l}1.5 \\
(0.0)\end{array}$ & $\begin{array}{c}1.6 \\
(0.0)\end{array}$ & $0 \%$ \\
\hline $25^{*}$ & 445 & 927 & $\begin{array}{l}\text { diclofenac } 75 \mathrm{mg} \\
\text { injection }\end{array}$ & $\begin{array}{l}8.1 \\
(1.0)\end{array}$ & $\begin{array}{l}3.9 \\
(0.4)\end{array}$ & $\begin{array}{l}6.0 \\
(0.2)\end{array}$ & $\begin{array}{l}5.3 \\
(0.3)\end{array}$ & $-25.9 \%$ \\
\hline 26 & 140 & 226 & $\begin{array}{l}\text { bromhexine } 8 \mathrm{mg} \\
\text { tablets }\end{array}$ & $\begin{array}{l}0.5 \\
(0.1)\end{array}$ & $\begin{array}{c}0.3 \\
(0.0)\end{array}$ & $\begin{array}{c}0.4 \\
(0.1)\end{array}$ & $\begin{array}{c}0.6 \\
(0.3)\end{array}$ & $-20 \%$ \\
\hline $27^{*}$ & 64 & 336 & $\begin{array}{l}\text { omeprazole } 20 \mathrm{mg} \\
\text { capsules }\end{array}$ & $\begin{array}{l}5.9 \\
(0.5)\end{array}$ & $\begin{array}{l}5.1 \\
(0.6)\end{array}$ & $\begin{array}{c}3.4 \\
(1.0)\end{array}$ & $\begin{array}{c}2.7 \\
(0.0)\end{array}$ & $-42.4 \%$ \\
\hline $28^{*}$ & 70 & 113 & ketotifen tablets & $\begin{array}{c}1.4 \\
(0.3)\end{array}$ & $\begin{array}{c}0.8 \\
(0.0)\end{array}$ & $\begin{array}{c}0.8 \\
(0.0)\end{array}$ & $\begin{array}{c}0.8 \\
(0.0)\end{array}$ & $-42.9 \%$ \\
\hline $29 *$ & 269 & 216 & $\begin{array}{l}\text { doxycycline } 100 \\
\text { mg capsules }\end{array}$ & $\begin{array}{c}2.8 \\
(0.0)\end{array}$ & $\begin{array}{c}1.3 \\
(0.2)\end{array}$ & $\begin{array}{l}1.0 \\
(0.0)\end{array}$ & $\begin{array}{c}1.5 \\
(0.0)\end{array}$ & $-64.3 \%$ \\
\hline 30 & 3 & 56 & $\begin{array}{l}\text { verapamil } 80 \mathrm{mg} \\
\text { tablets }\end{array}$ & $\begin{array}{c}2.2 \\
(0.5)\end{array}$ & $\begin{array}{c}1.2 \\
(0.0)\end{array}$ & $\begin{array}{l}1.6 \\
(0.0)\end{array}$ & $\begin{array}{l}1.7 \\
(0.0)\end{array}$ & $-27.3 \%$ \\
\hline
\end{tabular}

*Used in time-series analyses

**Difference in competitors' price from the quarter before the RPI was introduced to the end of the study period

***N No price for quarter before RPI intro; this price from quarter where RPI price first appears 
Table 3: Multivariate results of competitor price trends for 19 medicines before and after RPI introduction

Price Trends Before RPI are NOT Equal to Price Trends After RPI Medicine

B Immediate price effect of RPI§
C

Quarterly price trends before RPI
D

Quarterly price trends after RPI
Price Trends Before RPI are Equal to Price

Trends After RPI

\begin{tabular}{|c|c|c|c|c|}
\hline ampicillin 500 mg injection & $-1.19 * *$ & $-0.27^{* *}$ & 0.01 & \\
\hline atenolol $50 \mathrm{mg}$ tablets & $-0.52 * *$ & $-0.14^{*}$ & -0.05 & \\
\hline $\begin{array}{l}\text { metronidazole } 250 \mathrm{mg} \\
\text { tablets }\end{array}$ & $-0.35^{* *}$ & $-0.03^{* *}$ & 0.01 & \\
\hline $\begin{array}{l}\text { carbamazepine } 200 \mathrm{mg} \\
\text { tablets }\end{array}$ & $-1.04 *$ & $-0.22^{*}$ & -0.02 & \\
\hline diclofenac 75 mg injection & $-2.33^{* *}$ & $-0.34 * *$ & -0.07 & \\
\hline $\begin{array}{l}\text { doxycycline } 100 \mathrm{mg} \\
\text { capsules }\end{array}$ & $-1.19 * *$ & $-0.08 * *$ & -0.03 & \\
\hline $\begin{array}{l}\text { benzylpenicillin I g } \\
\text { injection }\end{array}$ & $0.06^{*}$ & & & $-0.02 * *$ \\
\hline $\begin{array}{l}\text { erythromycin } 250 \mathrm{mg} \\
\text { tablets }\end{array}$ & -0.07 & & & -0.01 \\
\hline amoxicillin $250 \mathrm{mg}$ tablets & $0.20 *$ & & & $-0.05^{* *}$ \\
\hline $\begin{array}{l}\text { ciprofloxacin } 250 \mathrm{mg} \\
\text { tablets }\end{array}$ & $-0.73^{*}$ & & & -0.01 \\
\hline $\begin{array}{l}\text { enalapril } 20 \text { mg tablets } \\
\left(\text { Ednyt }^{\circledR}\right)\end{array}$ & -0.18 & & & $-0.21 * *$ \\
\hline $\begin{array}{l}\text { ferrous sulfate+folic } \\
\text { acid+ascorbic acid tablets } \\
\left(\text { Gyno-Tardyferon }{ }^{\circledR}\right)\end{array}$ & $1.96^{*}$ & & & $0.26^{* *}$ \\
\hline $\begin{array}{l}\text { ferrous sulfate+ascorbic } \\
\text { acid tablets (Taryferon }{ }^{\circledR} \text { ) }\end{array}$ & 1.40 & & & $0.29 * *$ \\
\hline $\begin{array}{l}\text { nifedipine } 20 \text { mg retard } \\
\text { tablets (Corinafar Retard }{ }^{\circledR} \text { ) }\end{array}$ & $0.93 *$ & & & -0.06 \\
\hline prednisolone $5 \mathrm{mg}$ tablets & 0.38 & & & $-0.10 *$ \\
\hline $\begin{array}{l}\text { diclofenac } 25 \text { mg tablets } \\
\left.\text { (Ortophen }{ }^{\circledR}\right)\end{array}$ & -0.05 & & & $-0.01^{*}$ \\
\hline $\begin{array}{l}\text { metronidazole } 500 \mathrm{mg} \\
\text { vaginal suppositories }\end{array}$ & $-4.85^{* *}$ & & & $-0.27 * *$ \\
\hline omeprazole $20 \mathrm{mg}$ capsules & $0.75^{*}$ & & & $-0.30 * *$ \\
\hline ketotifen tablets & 0.18 & & & $-0.08 * *$ \\
\hline
\end{tabular}

$\S$ Difference in competitor price from the quarter before to the quarter after the RPI was introduced $*_{\mathrm{p}} \leq 0.05$

$* * p<0.0001$ 
cannot pinpoint theses critical components, we note the key characteristics of the RPI, including the role of highly trained and motivated players who genuinely wanted to develop and test new ways to increase access to essential medicines in rural areas. These staff devoted a great deal of their personal time and energy to seeing the project through, and it would be a mistake to overlook or underestimate the value of this social capital, especially in postSoviet Central Asia. From a social and political standpoint, the climate of Kyrgyzstan is recognized as being more conducive to civil society than that of any of its neighbors in Central Asia. However, with the exception of a few very strong professional organizations, the country's health sector NGOs tend to be less evolved than the NGO managing the RPI. In addition, the NGOs tend to be rather fractured, often working from outside the government rather than in collaboration with it. We therefore see a need for donors, international organizations, and governments to assist in reorganizing and building the capacity of existing NGOs to refocus their social capital toward more concrete activities, such as establishing and overseeing the RPIs.

Understanding that the majority of people in developing countries still seek care from pharmacies rather than public sector health facilities, many donors have been eager to develop private sector interventions but have been wary of engaging directly with the private sector. At the same time, donors are eager to establish and promote communitybased programs and civil society. The non-profit nature and involvement of civil society organizations in the rural pharmacy initiative model could provide donors with an opportunity to accomplish multiple goals without compromising their non-profit missions.

Lastly, the study reveals the utility of data on medicines that are routinely collected through mechanisms such as insurance schemes. These types of data sources are rich and should be used to build a solid body of evidence to guide policy on access to medicines for the poor. Research on interventions to increases access to medicines must include assessment of potential impact on both formal and informal markets. More work is needed to identify incentives for NGOs and other non-profits to engage in the establishment and management of rural pharmacies that can compete with existing private pharmacies. This should include determination of the operating costs to establish and maintain rural pharmacies and the minimum mark-ups needed to sustain these pharmacies, as well as pricing policies that promote rational use of medicines. Additional research is also needed to examine policies and programs that promote and impede competition in the pharmaceutical sector, including description of market size and structure, presence or absence of compe- tition laws, price regulation, barriers to market entry, and marketing.

\section{Conclusion}

Initiatives designed to increase equitable access to medicines in rural regions of developing and transitional countries should consider the potential to leverage medicine price competition as a means of achieving their goal. The inclusion of civil-society organizations and non-governmental organizations in the design and management of these initiatives, in collaboration with governments and international organizations, provides opportunities for capacity building, health sector development, and business development in rural regions that are often neglected.

\section{Competing interests}

The authors declare they have no competing interests.

\section{Authors' contributions}

BW designed and coordinated the study, participated in data cleaning and data analysis, and was the lead author on this paper. JM coordinated data collection and management, and participated in preparation of the manuscript. MG conducted data cleaning and data analysis and participated in preparation of the manuscript. YT assisted in data analysis and participated in preparation of the manuscript. RL and HL participated in the preparation of the manuscript. All authors read and approved the final manuscript.

\section{Additional material}

\section{Additional file 1}

Price trends for thirty top-selling medicines. RPI and non-RPI average price comparisons for the thirty top-selling medicines

Click here for file

[http://www.biomedcentral.com/content/supplementary/1475-

9276-8-43-S1.DOC]

\section{Acknowledgements}

This research was financed by a grant from the United States Agency for International Development through the Child and Family Applied Research Project at the Center for Global Health and Development at Boston University School of Public Health. Data collection for this study was carried out in collaboration with Maksat NGO in Kyrgyzstan. The following people provided support towards the design and/or implementation of the study: Damira Bibosunova, Neal Brandes, Christine Chaisson, Ellen Dierdrichsen, Mariam Djankorozova, Heather Haberle, Zina Hazeeva, Lucy Honig, Ainura Ibraimova, Elizabeth Lundeen, Tobias Schüth, Jonathon Simon, Lyne Soucy, and Michael Winter. 


\section{References}

I. Center for Pharmaceutical Management: Access to Essential Medicines: Tanzania, 200 I. In Strategies for Enhancing Access to Medicines Program Arlington, VA: Management Sciences for Health; 2003.

2. Quick JD: Essential medicines twenty-five years on:closing the access gap. Health Policy Plan 2003, I 8: I-3.

3. Quick JD: Ensuring access to essential medicines in the developing countries:A framework for action. Clin Pharmacol Ther 2003, 73:279-283.

4. Hogerzeil HV: Essential medicines and human rights:what can they learn from each other? Bull World Health Organ 2006 , 84:37I-375.

5. Mendis S, Fukino K, Cameron A, Laing R, Filipe JrA, Khatib O Leowski J, Ewen M: The availability and affordability of selected essential medicines for chronic diseases in six low- and middle-income countries. Bulletin of the World Health Organization 2007, 85:279-288.

6. Rutta E, Senauer K, Johnson K, Adeya G, Mbwasi R, Liana J, Kimatta $\mathrm{S}$, Sigonda M, Alphonce E: Creating a new class of pharmaceutical services provider for underserved areas:The Tanzania Accredited Drug Dispensing Outlet experience. Progress in Community Health Partnerships: Research, Education, and Action 2009, 3:145-153

7. Cameron A, Ewen M, Ross-Degnan D, Ball D, Laing R: Medicine prices, availability, and affordability in 36 developing and middle-income countries: a secondary analysis. Lancet 2009 373:240-249.

8. World Health Organization Regional Office for the Western Pacific: Regional strategy for improving access to essential medicines in the Western Pacific Region, 2005-20 I 0. In vol. Regional Committee EPR/RC55/9 Fifty-fifth session Shanghai, China: World Health Organization; 2004.

9. Babar ZUD, Ibrahim MIM, Singh H, Bukahri NI, Creese A: Evaluating Drug Prices, Availability, Affordability, and Price Components:Implications for Access to Drugs in Malaysia. PLoS Medicine 2007, 4:0466-0475.

10. Millenium Development Goal Gap Task Force: Delivering on the Global Partnership of Achieving the Millenium Development Goals:Millenium Development Goal 8. New York: United Nations; 2008

II. Gelders S, Ewen M, Noguchi N, Laing R: Price, availability and affordability: An international comparison of chronic disease medicines. 2006. WHO-EM/EDB/068/E/05.06/3000 edition. Cairo

12. Patouillard E, Goodman C, Hanson K, Mills A: Can working with the private for-profit sector improve utilization of quality health services by the poor? A systematic review of the literature. Int J Equity in Health 2007, 6: I7.

13. Hardeman W, Van Damme W, Van Pelt M, Por I, Kimvan H, Meessen B: Access to health care for all? User fees plus a Health Equity Fund in Sotnikum, Cambodia. Health Policy Plan 2004, 19:22-32.

14. Umenai T, Narula IS: Revolving drug funds:a step towards health security. Bull World Health Organ 1999, 77:167-171.

15. Svhakhang L, Sengaloundeth S, Freudenthal S, Walhstrom R: Availability of essential drugs and sustainability of village revolving drug funds in remote areas of Lao PDR. In Health and social protection: experiences from Cambodia, China and Lao PDF 23rd edition. Edited by: Meessen B, Pei X, Criel B, Bloom G. Antwerp: ITG Press; 2008:519-543. [Van Lerberghe W, Kegels G, De Brouwere V (Series Editor): Studies in Health Services Organisation \& Policy]

16. von Massow F, Korte R, Cheka C, Kuper M, Tata H, Schmidt-Ehry B Financially independent primary health care drug supply system inCameroun. Trop Med Int Health 1998, 3:788-80I

17. Ali GKM: How to establish a successful revolving drug fund:the experience of Khartoum state in the Sudan. Bull World Health Organ 2009, 87: I39-142.

18. Ali GKM: Accessibility of medicines and primary health care:The impact of the revolving drug fund in Khartoum State. African Journal of Pharmacy and Pharmacology 2009, 3:70-77.

19. Witter S: Achieving sustainability, quality and access:lessons from the world's largest revolving drug fund in Khartoum. Eastern Mediterranean Health Journal 2007, I 3: | 476- | 485.

20. Africare Community Health and Partnerships Program: Drug Revolving Fund Supervisory Tool: a Job Aid for Supervisors. Africare Washington, D.C 200I.

21. Hamada A: Essential drug revolving fund programme within the context of pharmaceutical development of Vietnam. Pro gramme: Evaluation of Nippon Foundation Drug Revolving Fund Project in Asia 1999.

22. Cross PN, Huff MA, Quick JD, Bates JA: Revolving drug funds: Conducting business in the public sector. Soc Sci Med 1986, 22:335-343.

23. Waddington $\mathrm{C}$, Panza A: Ten questions to ask about revolving drug funds. Trop Doct |99|, 2 |:50-53.

24. McPake $B$, Hanson $K$, Mills A: Community financing of health care in Africa: An evaluation of the Bamako initiative. Soc Sci Med 1993, 36:1383-1395.

25. Osore $\mathrm{H}$ : The role of revolving drug funds in strengthening MCH/PHC services in Liberia. Eur J Public Health 1993 , 3:133-136.

26. Fiedler JL, Wight JB: Financing health care at the local level: the community drug funds of Honduras. Int J Health Plan Manage 2000, I 5:319-340.

27. Gilson L, Kalyalya D, Kuchler F, Lake S, Oranga H, Ouendo M: Strategies for promoting equity: experience with community financing in three African countries. Health Policy 200I, 58:37-67.

28. Turshen M: Reprivatizing pharmaceutical supplies in Africa. Public Health Policy 2001, 22:198-225.

29. Murakami H, Phommasack B, Oula R, Sinxomphou S: Revolving drug funds at front-line health facilities in Vientiane, Lao PDR. Health Policy Plan 2001, 16:98-106.

30. Uzochukwu B, Onwujekwe O: Healthcare reform involving the introduction of user fees and drug revolving funds: influence on health workers' behavior in southeast Nigeria. Health Policy 2005, 75: I-8

31. Sambo MN, Lewis I, Sabitu K: Essential drugs in primary health centres of north central Nigeria; where is Bamako initiative? Nigerian J Clin Practice 2008, I I:9-I3

32. Diallo I, McKeown S, Wone I: Bamako boost for primary care. World Health Forum 1996, 1 7:382-385

33. Huff MA, Rizal A: 20 Years of Revolving Drug Funds: Should the public sector conduct business? Public Health and Human Rights: APHA 134th Annual Meeting and Exposition. Boston, MA 2006.

34. United Nations Childrens Fund: Equity of access in the implemenation of the Bamako initiative: research on the Bamako initiative in Vietnam. Hanoi 1994.

35. Management Sciences for Health: Tanzania: Accredited Drug Dispensing Outlets-Duka la Dawa Muhimu. Management Sciences for Health; 2007.

36. Central Intelligence Agency: World Fact Book. Central Intelligence Agency. 2009.

37. Schüth T: Community Action for Health in Kyrgyzstan: Approach and first results of the pilot project in Naryn Oblast, Kyrgyzstan. Bishkek: Kyrgyz-Swiss Health Reform Support Project; 2004.

38. Waning B, Jakab M, Jafarov A, Checheibev E: Project evaluation of a rural pharmacy pilot in Jumgal Rayon, Kyrgyzstan. In Policy Research Paper \#38 Bishkek: WHO-DfID Manas Health Policy Analysis Project; 2006.

39. Kadyrova N, Waning B, Cashin C: Kyrgyzstan outpatient drug (OPD) benefit program: Use of automated claims data to evaluate the impact of the OPD benefit program on rational drug prescribing by physicians and generic drug use by patients. Second International Conference on Improving the Use of Medicines. Chiang Mai, Thailand 2004.

40. Health Policy Analysis Project: Trends in public and private spending on health in the Kyrgyz Republic (2000-03). In Policy Research Paper \#38 Bishkek: WHO-DfID Manas Health Policy Analysis Project; 2005

4I. Waning B, Maddix J, Djankorozova M, Gokhale M, Winter M, Diedrichsen E, Jafarov A: Improving rural access to medicines in Kyrgyzstan: a view through the lenses of insurance, households, communities, and retail pharmacy business. Boston: Boston University School of Medicine; 2009.

42. International Monetary Fund: World Economic OutlookDatabase. vol. Washington DC: International Monetary Fund; 2009.

43. Uzochukwu BSC, Onwujekwe OE, Akpala CO: Effect of the Bamako-Initiative drug revolving fund on availability and rational use of essential drugs in primary health care facilities in south-east Nigeria. Health Policy Plan 2002, I 7:378-383. 